\title{
Development of leaf silvering in squash cultivars infested by silverleaf whitefly
}

\author{
André Luiz Lourenção; André C Alves; Arlete MT de Melo; Giuliana E do Valle \\ Instituto Agronômico, C. postal 28, 13012-970 Campinas-SP; andre@iac.sp.gov.br
}

\begin{abstract}
The silverleaf whitefly Bemisia tabaci biotype B is one of the most harmful insect pests for agricultural and vegetable crops. Beside the direct damage, it transmits pathogenic virus and induces plant physiological disorders, such as the squash silverleaf disorder. In this research we evaluated the development of leaf silvering in squash cultivars submitted to artificial infestation of B. tabaci biotype B. An experiment was conducted under field conditions, in Campinas, São Paulo State, Brazil, during the season 2003-2004. The germplasm (Cucurbita spp.) comprised of seven cultivars of summer squash and nine of bush squash. The experiment used a complete randomized blocks design, with 16 treatments (cultivars) and five replications. Each plot consisted of two plants. The artificial infestation was done when the plants emitted the third pair of leaves, by transplanting soybean plants infested with silverleaf whitefly between the squash plots. The leaf silvering was evaluated every two or three days, using a rating scale varying from 1 (no symptom) to 5 (leaves completely silvered). The highest level (5.0) was observed in 'Baianinha', 'Golden Delight', 'Caravela' and 'Arlika', while 'Novita' (2.5), 'Atlas' (2.0) and 'Atlanta AG-303' (1.5) showed light symptoms, indicating that these have low sensibility to this physiological disorder.
\end{abstract}

Keywords: Cucurbita spp., Bemisia tabaci (Genn.) biotype B, Aleyrodidae, silverleaf whitefly, squash silverleaf disorder.

\section{RESUMO}

Prateamento das folhas em cultivares de aboboreira infestadas por mosca-branca

A mosca-branca (Bemisia tabaci biótipo B) é uma das mais nocivas pragas da agricultura. Além de danos diretos, transmite vírus e também induz desordens fisiológicas, como o prateamento-dasfolhas-da-aboboreira. No presente trabalho, avaliou-se o prateamento em folhas de cultivares de aboboreiras, submetidas à infestação artificial de $B$. tabaci biótipo B. Um experimento foi conduzido em condições de campo, em Campinas-SP, no ano agrícola 2003-2004, com 16 cultivares de aboboreira (Cucurbita spp.), sendo sete de hábito de crescimento rasteiro e nove de moita. Utilizou-se delineamento de blocos ao acaso, com 16 tratamentos (cultivares) e cinco repetições, sendo cada parcela formada por duas plantas. Procedeu-se à infestação da área experimental por meio de transplante de plantas de soja infestadas pela mosca-branca entre as aboboreiras, quando estas emitiram o terceiro par de folhas. A evolução do prateamento nas folhas foi avaliada a cada dois ou três dias, mediante uso de escala de notas variando de 1 (sem sintomas) a 5 (folha completamente prateada). 'Baianinha', 'Golden Delight', 'Caravela' e 'Arlika' apresentaram grau máximo de prateamento das folhas (média 5,0) enquanto 'Novita' (2,5), 'Atlas' $(2,0)$ e 'Atlanta AG-303' (1,5) exibiram sintomas amenos, caracterizando-se como menos sensíveis a essa desordem fisiológica.

Palavras-chave: Cucurbita spp., Bemisia tabaci (Genn.) biótipo B, Aleyrodidae, mosca-branca, desordem fisiológica, prateamento-dasfolhas-da-aboboreira.

(Recebido para publicação em 19 de agosto de 2009; aceito em 2 de setembro de 2010) (Received on August 19, 2009; accepted on September 2, 2010)

$\mathrm{T}$ he whitefly Bemisia tabaci (Genn.) biotype B, also known as $B$. argentifolii Bellows \& Perring, is one of the most destructive agricultural pests, attacking vegetables, ornamental species and field crops in the field or in greenhouse, in tropical and subtropical regions worldwide (Chen et al., 2004). High infestations of whitefly may alter plant physiological processes, reducing transpiration and photosynthesis, causing loss of vigor and subsequent reduction in plant development, due to the feeding of nymphs and adults (Inbar \& Gerling, 2008; Mc Auslane et al., 2004). Secretions deposited by the insect on the leaves are a suitable medium for the development of sooty mold, which impairs photosynthesis (Davidson et al., 1994) and can also contaminate products from plants, which occurs, for example, in the staining of the fibers in cotton (Henneberry et al., 2000). B. tabaci biotype $\mathrm{B}$ is also an efficient vector of dozens of viruses, some of them important for crops in different regions of the world (Brown \& Czosnek, 2002; Hilje \& Morales, 2008).

Another type of damage that this biotype can cause is the induction of physiological disorders such as irregular ripening of tomato fruits and the squash leaf silvering. The squash leaf silvering was first recorded in Israel in the 1960's and was attributed to drought stress (Burger et al., 1988). In the 1980's, this abnormality was observed in Florida and it was associated to the presence of B. tabaci (Maynard \& Cantliffe, 1989). Yokomi et al. (1990) found that leaf silvering symptoms appeared three days after the initiation of nymph feeding and that adult feeding was not associated to the disorder. Later studies also demonstrated the association between the feeding of $B$. tabaci biotype $B$ nymphs and the squash leaf silvering (Schuster et al., 1991; Hoelmer et al., 1991; Costa et al., 1993). Later, De Barro \& Khan (2007) showed that the adult stage of this biotype of $B$. 
tabaci is also capable of inducing leaf silvering, provided there is adequate adult infestation for more than 11 days.

After the discovery of the ability of the biotype $\mathrm{B}$ to induce this disorder, other biotypes were also found to induce silvering in squash leaves: biotype Ms (Delatte et al., 2005) and biotype Ug6 (Sseruwagi et al., 2005). The current distribution of these two biotypes is restricted to islands in the Indian Ocean and Africa.

When the infestation of whitefly on the squash is controlled with insecticides or removal of infested leaves, the symptomatic leaves remain symptomatic, but the new leaves are normal (Yokomi et al., 1990). However, if the infestation continues until the reproductive phase, reduction in yield and fruit quality may occur; according to Chen et al. (2004), fruits of plants infested by B. tabaci biotype B present reduction in the levels of chlorophyll and carotenoids, consequently, the fruits become bleached with lower commercial value.

Not only plants of the three main cultivated species of Cucurbita $[C$. pepo L., C. maxima Duch. ex Poir and C. moschata (Duch. ex Lam.)] present symptoms of this disorder, showing sensitivity to that whitefly (Paris et al., 1993) but also wild species such as $C$. ecuadorensis and $C$. martinezii (McAuslane et al., 1996). Nevertheless, differences in susceptibility to the leaf silvering have been observed in species of Cucurbita. Evaluating accessions of the U.S. National Germplasm System, USA, planted in an area naturally infested by B. tabaci biotype B in Puerto Rico, Wessel-Beaver (1997) found genotypes of the species $C$. moschata, $C$. pepo and $C$. maxima with high resistance to this disorder.

This study aimed to identify among summer and bush squash cultivars, the ones which do not show symptoms of leaf silvering or which express it in a less intense way, when infected by B. tabaci biotype $\mathrm{B}$.

\section{MATERIAL AND METHODS}

B - To initiate the rearing, adults of whitefly were collected from a tomato field in Paulínia, São Paulo State, and transferred to plants of soybean and cabbage under greenhouse in the Instituto Agronômico de Campinas (IAC), São Paulo State. After advancing a few generations, adults were sent to Dr. Judith K. Brown, University of Arizona, USA, who identified them as belonging to the biotype B of B. tabaci. This identification is confirmed periodically through the cultivation of squash plants within the rearing greenhouse inducing these plants to express the leaf silvering, the physiological disorder caused by the feeding of immature insects of that biotype (Brown et al., 1995).

Installation of experiments and evaluations - Under field conditions, in an area of the Centro Experimental of Campinas (IAC), São Paulo State, (22 $2^{\circ} 3^{\prime} \mathrm{S}, 47^{\circ} 04^{\prime} \mathrm{W}, 674 \mathrm{~m}$ height), the assay to evaluate the evolution of the leaf-silvering was settled with sixteen squash cultivars of the species $C$. maxima, $C$. moschata, $C$. pepo and $C$. maxima $\mathrm{x} C$. moschata. (Table 1). These cultivars comprise the main hybrids and varieties of squash developed and released from private and official companies. Four of them are referred as tolerant to viruses species: 'Atlanta AG303 ' to Papaya ring spoty virus (PRSV); 'Golden Delight' to Zucchini yellow mosaic virus (ZYMV) and Watermelon mosaic virus (WMV); 'Revenue' to ZYMV, WMV and Cucumber mosaic virus (CMV) and 'Sandy' to PRSV and to powdery mildew strain 1 .

For seeding, polystyrene trays with 72 cells were used, which were filled with the substrate Plantmax ${ }^{\circledR}$ and kept in a greenhouse for two weeks. For transplanting, which was carried out on November $27^{\text {th }}$, 2003, 80 pits of about $25 \mathrm{~cm}$ depth, fertilized with $200 \mathrm{~g}$ of the formula 4-14-8 were prepared. Spacing was $4 \times 3 \mathrm{~m}$, which provided $12 \mathrm{~m}^{2}$ for each cultivar, regardless the growth habit. Each pit received two plantlets. Top-dressing was carried out with $30 \mathrm{~g}$ of the formula 20-5-20, and an irrigation with nitrocalcium according to the soil analysis and the references for this crop (Raij et al., 1997).

Irrigation was carried out daily through watering can in order to meet the water necessity of the plants. Despite the proximity between the experimental area and the place of rearing of the whitefly, with possible infestation by the insect without human interference, we chose to perform an artificial infestation in the experiment. Thus, pots containing two highly-infested soybean plants were transferred from the insect rearing greenhouse to the experimental area two weeks after transplanting, after the emission of the third pair of leaves of the squash plants. Each pot, presenting on average eight leaflets with about 300 adults per leaflet was transplanted equally spaced from the plots, one for four pits. The leaf-silvering evolution was evaluated in each cultivar through a graded scale varying from 1 to 5 (Alves, 2005), adapted from the scale proposed by Paris et al. (1987). The grade 1 means absence of symptoms on leaves and the others indicate the gradual development of the symptoms, it means, the silvering intensity, up to the grade 5, which refers to the totally silver leaf. The field evaluations were carried out each two or three days, resulting 18 reads, assigning one grade representative of each plant of the plot, considering the leaves with the most expressive symptom.

Statistic procedures - The experimental design was of randomized blocks, composed of sixteen treatments (Table 1) repeated five times, totalling 80 plots. Each plot was a pit containing two squash plants. In each plot, the value was obtained by averaging the scores assigned to each plant. Due to the absence of data normality, data were analyzed through the Friedman nonparametric test and the means were compared using the multiple comparison test, at $5 \%$ of probability using the statistic program BioEstat.

\section{RESULTS AND DISCUSSION}

The first evaluation was performed the day after the artificial infestation, two weeks after transplanting, when there was no difference between the grades of the cultivars (Table 2). However, 'Golden Delight' and 'Baianinha' had average scores of 3.5 and 2.0 respectively, and, also, 'Golden Dawn 
Table 1. Squash cultivars (Cucurbita spp.) evaluated for leaf silvering induced by Bemisia tabaci biotype B (cultivares de aboboreiras (Cucurbita spp.) avaliadas em relação ao prateamento das folhas induzido por Bemisia tabaci biótipo B). Campinas, IAC, 2003/2004.

\begin{tabular}{|c|c|c|}
\hline Group & Cultivar & Species \\
\hline \multirow{9}{*}{ Bush } & Arlika & C. реро \\
\hline & Atlanta AG-303 & C. реро \\
\hline & Caserta & C. реро \\
\hline & Golden Dawn III & C. реро \\
\hline & Golden Delight & C. реро \\
\hline & Novita & C. реро \\
\hline & Raven & C. реро \\
\hline & Revenue & C. реро \\
\hline & Wafra & C. реро \\
\hline \multirow{7}{*}{ Summer } & Atlas & C. moschata \\
\hline & Baianinha & C. moschata \\
\hline & Bárbara & C. moschata \\
\hline & Caravela & C. moschata \\
\hline & Menina Brasileira & C. moschata \\
\hline & Exposição & C. maxima \\
\hline & Tetsukabuto & C. maxima x C. moschata \\
\hline
\end{tabular}

III' and 'Atlanta AG-303', scored 1.5 , which indicates that, even before the artificial infestation, the squash plantlets had already been infested by B. tabaci biotype B, since the silverleaf symptoms appear three to five days after the exposure to nymphs (Yokomi et al., 1990) or from nine to eleven days after the exposure to adults (Hoelmer et al., 1991). By the second evaluation, carried out two days after the first one, the leaves of 'Golden Delight' showed intense silvering, with average grade 4.0; by this evaluation, except for 'Golden Dawn III' and 'Baianinha', with average grades of 2.5 , the other cultivars showed a less intense degree of leaf-silvering. In the third evaluation, there was little change in relation to the grades of the previous evaluation. From the fourth evaluation, the most sensitive cultivars to this physiological disorder began to express more intensively the leaf-silvering, such as 'Baianinha' which, in the fifth assessment, averaged 5.0, the highest possible score. The second cultivar to achieve the maximum grade of silvering was 'Golden Delight', eleven days after infestation, in the $7^{\text {th }}$ evaluation. 'Caravela' and 'Arlika', in the $10^{\text {th }}$ and $17^{\text {th }}$ evaluations, respectively, also achieved grade 5.0, which characterized them as highly sensitive. Even eighteen days after the infestation of B. tabaci biotype $\mathrm{B}$, in the $8^{\text {th }}$ evaluation, 'Exposição' differed from the most sensitive genotypes. However, in the following evaluations, the symptoms of this genotype changed and reached an average of 4.0 in the last evaluation. Thus, this cultivar behaved as susceptible.

Among the cultivars with lower rates of silvering, 'Novita', 'Atlas' and 'Atlanta AG-303', had the lowest grades of silvering throughout the crop season. It should be mentioned that 'Novita' and 'Atlas' are among the cultivars less attractive and less oviposited by $B$. tabaci biotype B while 'Atlanta GA$303^{\prime}$ is one of the cultivars with the greatest oviposition by this insect (Alves et al., 2005). Thus, the factors which determine the sensitivity to the leafsilvering may be different from the ones which determine the resistance against the insect. In this way, Cardoza et al. (1999) submitted the strains ZUC76SLR and ZUC33-SLR/PMR, tolerant to leaf-silvering, and the cultivar Zucchini Elite, to different levels of infestation of adults of $B$. tabaci biotype B. They found that, even in the presence of 160 couples (maximum infestation), 'ZUC76-SLR' showed no symptoms, whereas half of that infestation ( 80 couples) was enough to induce 'ZUC33-SLR/PMR' to present a moderate leaf-silvering. 'Zucchini Elite' developed the maximum degree of silvering with lower infestation, 40 couples of whitefly. Differences in the intensity of the leaf-silvering in strains of zucchini squash (C.pepo), infested by B. tabaci biotype B were also found by McAuslane et al. (2004) in the U.S.A. In an experiment carried out in the summer, these authors found intense silvering in plants of 'ZUC61', whereas 'ZUC76SLR' plants did not exhibit symptoms. They also found the effect of planting date on the expression of this disorder, since, in an experiment carried out in the fall, plants of the strain 'ZUC76-SLR' showed light symptoms of silverleaf. Given this fact, it is of interest to install experiments with the cultivars of this research in order to evaluate the development of the leaf-silvering symptoms in this germplasm, especially for the least sensitive genotypes, such as 'Novita', 'Atlas' and 'Atlanta AG303 'in different seasons in Brazilian conditions.

Besides being highly oviposited, 'Golden Delight' is one of the most attractive varieties to adults (Alves et $a l ., 2005)$. This genotype also provides the shortest development time from egg to adult and the highest adult emergence of B. tabaci biotype B (Alves et al., 2005). In agreement with these data, in the present research we found that 'Golden Delight' is also, among the most sensitive genotypes to the leafsilvering. Given these characteristics, growing this cultivar should be avoided under high pressure of $B$. tabaci biotype $B$ or proper management of this insect should be carried out in these occasions. 'Golden Delight' can also be used as a susceptible control for studies of sensitivity to leaf-silvering and of resistance to whitefly in squash.

In this work, cultivars such as 'Novita', 'Atlas' and 'Atlanta AG-303' were found to be less sensitive to the leaf-silvering. Similarly to the American genotypes that show no symptoms or very light symptoms (McAuslane et al., 1996), these genotypes exhibited light symptoms of leaf-silvering even under 
Table 2. Development of leaf silvering in sixteen squash cultivars submitted to artificial infestation of B. tabaci biotype B, evaluated through a rating scale ${ }^{1}$ (evolução do prateamento em folhas, avaliado mediante escala de notas ${ }^{1}$, em dezesseis cultivares de aboboreira, submetidas em campo à infestação de B. tabaci biótipo B). Campinas, IAC, 2003/2004.

\begin{tabular}{|c|c|c|c|c|c|c|c|c|c|}
\hline \multirow{2}{*}{ Cultivar } & \multicolumn{9}{|c|}{ Average scores attributed to each cultivar in each evaluation ${ }^{2}$} \\
\hline & $1^{\text {st }}$ & $2^{\text {nd }}$ & $3^{\text {rd }}$ & $4^{\text {th }}$ & $5^{\text {th }}$ & $6^{\text {th }}$ & $7^{\text {th }}$ & $8^{\text {th }}$ & $9^{\text {th }}$ \\
\hline Baianinha & $2.0 \mathrm{a}$ & $2.5 \mathrm{ab}$ & $2.5 \mathrm{abc}$ & $4.0 \mathrm{a}$ & $5.0 \mathrm{a}$ & $5.0 \mathrm{a}$ & $5.0 \mathrm{a}$ & $5.0 \mathrm{a}$ & $5.0 \mathrm{a}$ \\
\hline Golden Delight & $3.5 \mathrm{a}$ & $4.0 \mathrm{a}$ & $4.5 \mathrm{a}$ & $4.5 \mathrm{a}$ & $4.5 \mathrm{ab}$ & $4.5 \mathrm{a}$ & $5.0 \mathrm{a}$ & $5.0 \mathrm{a}$ & $5.0 \mathrm{a}$ \\
\hline Caravela & $1.0 \mathrm{a}$ & $1.0 \mathrm{c}$ & $1.0 \mathrm{~d}$ & $2.0 \mathrm{abc}$ & $3.5 \mathrm{abc}$ & $4.5 \mathrm{a}$ & $4.5 \mathrm{ab}$ & $4.5 \mathrm{ab}$ & $4.5 \mathrm{ab}$ \\
\hline Arlika & $1.0 \mathrm{a}$ & $1.0 \mathrm{c}$ & $1.5 \mathrm{bcd}$ & $2.5 \mathrm{abc}$ & $3.0 \mathrm{abc}$ & $4.0 \mathrm{ab}$ & $4.0 \mathrm{abc}$ & $4.0 \mathrm{abc}$ & $4.0 \mathrm{abc}$ \\
\hline Golden Dawn III & $1.5 \mathrm{a}$ & $2.5 \mathrm{ab}$ & $3.5 \mathrm{ab}$ & $3.5 \mathrm{ab}$ & $3.5 \mathrm{abc}$ & $4.0 \mathrm{ab}$ & $4.0 \mathrm{abc}$ & $4.0 \mathrm{abc}$ & $4.0 \mathrm{abc}$ \\
\hline Raven & $1.0 \mathrm{a}$ & $1.5 \mathrm{bc}$ & $2.0 \mathrm{bcd}$ & $3.0 \mathrm{abc}$ & $3.5 \mathrm{abc}$ & $3.5 \mathrm{ab}$ & $4.0 \mathrm{abc}$ & $4.0 \mathrm{abc}$ & $4.0 \mathrm{abc}$ \\
\hline Menina Brasileira & $1.0 \mathrm{a}$ & $1.5 \mathrm{bc}$ & $1.5 \mathrm{bcd}$ & $2.0 \mathrm{abc}$ & $2.5 \mathrm{bcd}$ & $2.5 \mathrm{ab}$ & $3.0 \mathrm{abc}$ & $3.5 \mathrm{abcd}$ & $4.0 \mathrm{abc}$ \\
\hline Wafra & $1.0 \mathrm{a}$ & $1.0 \mathrm{c}$ & $1.5 \mathrm{abcd}$ & $2.0 \mathrm{abc}$ & $3.0 \mathrm{abc}$ & $3.5 \mathrm{ab}$ & $3.5 \mathrm{abc}$ & $4.0 \mathrm{abc}$ & $4.0 \mathrm{abc}$ \\
\hline Bárbara & $1.0 \mathrm{a}$ & $1.5 \mathrm{c}$ & 2.0abcd & $2.5 \mathrm{abc}$ & $3.0 \mathrm{abc}$ & $3.0 \mathrm{ab}$ & $3.5 \mathrm{abc}$ & $3.5 \mathrm{abcd}$ & $3.5 \mathrm{bcd}$ \\
\hline Exposição & $1.0 \mathrm{a}$ & $1.0 \mathrm{c}$ & $1.0 \mathrm{~d}$ & $1.5 \mathrm{c}$ & $1.5 \mathrm{~d}$ & $2.0 \mathrm{~b}$ & $2.0 \mathrm{bc}$ & $2.5 \mathrm{bcd}$ & $3.0 \mathrm{bcd}$ \\
\hline Tetsukabuto & $1.0 \mathrm{a}$ & $2.0 \mathrm{bc}$ & 2.0abcd & $2.5 \mathrm{abc}$ & $3.0 \mathrm{abc}$ & $3.0 \mathrm{ab}$ & $3.0 \mathrm{abc}$ & 3.0abcd & $3.0 \mathrm{bcd}$ \\
\hline Revenue & $1.0 \mathrm{a}$ & $1.5 \mathrm{bc}$ & $1.5 \mathrm{bcd}$ & $1.5 \mathrm{c}$ & $2.0 \mathrm{~cd}$ & $2.5 \mathrm{ab}$ & $2.5 \mathrm{abc}$ & $3.0 \mathrm{abcd}$ & $3.0 \mathrm{bcd}$ \\
\hline Caserta & $1.0 \mathrm{a}$ & $2.0 \mathrm{bc}$ & 2.0abcd & $2.5 \mathrm{abc}$ & $3.0 \mathrm{abc}$ & $3.0 \mathrm{ab}$ & $3.0 \mathrm{abc}$ & $3.0 \mathrm{abcd}$ & $3.5 \mathrm{bcd}$ \\
\hline Novita & $1.0 \mathrm{a}$ & $1.0 \mathrm{c}$ & $1.0 \mathrm{~d}$ & $1.5 \mathrm{c}$ & $2.0 \mathrm{~cd}$ & $2.0 \mathrm{~b}$ & $2.0 \mathrm{bc}$ & $2.0 \mathrm{~cd}$ & $2.0 \mathrm{~cd}$ \\
\hline Atlas & $1.0 \mathrm{a}$ & $1.0 \mathrm{c}$ & $1.0 \mathrm{~d}$ & $1.5 \mathrm{c}$ & $1.5 \mathrm{~d}$ & $1.5 \mathrm{~b}$ & $1.5 \mathrm{c}$ & $1.5 \mathrm{~d}$ & $1.5 \mathrm{~d}$ \\
\hline Atlanta AG-303 & $1.5 \mathrm{a}$ & $1.5 \mathrm{bc}$ & $1.5 \mathrm{bcd}$ & $1.5 \mathrm{c}$ & $1.5 \mathrm{~d}$ & $1.5 \mathrm{~b}$ & $1.5 \mathrm{c}$ & $1.5 \mathrm{~d}$ & $1.5 \mathrm{~d}$ \\
\hline \multirow[t]{2}{*}{ Average value } & 1.3 & 1.7 & 1.9 & 2.4 & 2.9 & 3.1 & 3.3 & 3.4 & 3.5 \\
\hline & $10^{\text {th }}$ & $11^{\text {th }}$ & $12^{\text {th }}$ & $13^{\text {th }}$ & $14^{\text {th }}$ & $15^{\text {th }}$ & $16^{\text {th }}$ & $17^{\text {th }}$ & $18^{\text {th }}$ \\
\hline Baianinha & $5.0 \mathrm{a}$ & $5.0 \mathrm{a}$ & $5.0 \mathrm{a}$ & $5.0 \mathrm{a}$ & $5.0 \mathrm{a}$ & $5.0 \mathrm{a}$ & $5.0 \mathrm{a}$ & $5.0 \mathrm{a}$ & $5.0 \mathrm{a}$ \\
\hline Golden Delight & $5.0 \mathrm{a}$ & $5.0 \mathrm{a}$ & $5.0 \mathrm{a}$ & $5.0 \mathrm{a}$ & $5.0 \mathrm{a}$ & $5.0 \mathrm{a}$ & $5.0 \mathrm{a}$ & $5.0 \mathrm{a}$ & $5.0 \mathrm{a}$ \\
\hline Caravela & $5.0 \mathrm{a}$ & $5.0 \mathrm{a}$ & $5.0 \mathrm{a}$ & $5.0 \mathrm{a}$ & $5.0 \mathrm{a}$ & $5.0 \mathrm{a}$ & $5.0 \mathrm{a}$ & $5.0 \mathrm{a}$ & $5.0 \mathrm{a}$ \\
\hline Arlika & $4.0 \mathrm{ab}$ & $4.0 \mathrm{ab}$ & $4.0 \mathrm{ab}$ & $4.0 \mathrm{ab}$ & $4.5 \mathrm{ab}$ & $4.5 \mathrm{ab}$ & $4.5 \mathrm{a}$ & $5.0 \mathrm{a}$ & $5.0 \mathrm{a}$ \\
\hline Golden Dawn III & $4.0 \mathrm{ab}$ & $4.0 \mathrm{ab}$ & $4.0 \mathrm{ab}$ & $4.5 \mathrm{a}$ & $4.5 \mathrm{ab}$ & $4.5 \mathrm{ab}$ & $4.5 \mathrm{a}$ & $4.5 \mathrm{a}$ & $4.5 \mathrm{ab}$ \\
\hline Raven & $4.0 \mathrm{ab}$ & $4.0 \mathrm{ab}$ & $4.0 \mathrm{ab}$ & $4.0 \mathrm{ab}$ & $4.5 \mathrm{ab}$ & $4.5 \mathrm{ab}$ & $4.5 \mathrm{a}$ & $4.5 \mathrm{a}$ & $4.5 \mathrm{ab}$ \\
\hline Menina Brasileira & $4.0 \mathrm{ab}$ & $4.0 \mathrm{ab}$ & $4.0 \mathrm{ab}$ & $4.0 \mathrm{ab}$ & $4.0 \mathrm{abc}$ & $4.5 \mathrm{ab}$ & $4.5 \mathrm{a}$ & $4.5 \mathrm{a}$ & $4.5 \mathrm{ab}$ \\
\hline Wafra & $4.0 \mathrm{ab}$ & $4.0 \mathrm{ab}$ & $4.0 \mathrm{ab}$ & $4.0 \mathrm{ab}$ & $4.0 \mathrm{abc}$ & $4.0 \mathrm{abc}$ & $4.0 \mathrm{ab}$ & $4.0 \mathrm{ab}$ & $4.0 \mathrm{abc}$ \\
\hline Bárbara & $3.5 \mathrm{abc}$ & $3.5 \mathrm{abc}$ & $3.5 \mathrm{ab}$ & $4.0 \mathrm{ab}$ & $4.0 \mathrm{abc}$ & $4.0 \mathrm{abc}$ & $4.0 \mathrm{ab}$ & $4.0 \mathrm{ab}$ & $4.0 \mathrm{abc}$ \\
\hline Exposição & $3.0 \mathrm{bcd}$ & $3.0 \mathrm{bcd}$ & $3.5 \mathrm{ab}$ & $3.5 \mathrm{ab}$ & $3.5 \mathrm{abc}$ & $3.5 \mathrm{abc}$ & $3.5 \mathrm{ab}$ & $3.5 \mathrm{ab}$ & $4.0 \mathrm{abc}$ \\
\hline Tetsukabuto & $3.5 \mathrm{abc}$ & $3.5 \mathrm{abc}$ & $3.5 \mathrm{ab}$ & $3.5 \mathrm{ab}$ & $3.5 \mathrm{abc}$ & $3.5 \mathrm{abc}$ & $3.5 \mathrm{ab}$ & $4.0 \mathrm{ab}$ & $4.0 \mathrm{abc}$ \\
\hline Revenue & $3.0 \mathrm{bcd}$ & $3.0 \mathrm{bcd}$ & $3.0 \mathrm{ab}$ & $3.5 \mathrm{ab}$ & $3.5 \mathrm{abc}$ & $3.5 \mathrm{abc}$ & $3.5 \mathrm{ab}$ & $3.5 \mathrm{ab}$ & $3.5 \mathrm{bcd}$ \\
\hline Caserta & $3.5 \mathrm{abc}$ & $3.5 \mathrm{abc}$ & $3.5 \mathrm{ab}$ & $3.5 \mathrm{ab}$ & $3.5 \mathrm{abc}$ & $3.5 \mathrm{abc}$ & $3.5 \mathrm{ab}$ & $3.5 \mathrm{ab}$ & $3.5 \mathrm{bcd}$ \\
\hline Novita & $2.0 \mathrm{~cd}$ & $2.0 \mathrm{~cd}$ & $2.0 \mathrm{~b}$ & $2.0 \mathrm{~b}$ & $2.0 \mathrm{bc}$ & $2.0 \mathrm{bc}$ & $2.0 \mathrm{~b}$ & $2.0 \mathrm{~b}$ & $2.5 \mathrm{bcd}$ \\
\hline Atlas & $1.5 \mathrm{~d}$ & $1.5 \mathrm{~d}$ & $1.5 \mathrm{~b}$ & $1.5 \mathrm{~b}$ & $1.5 \mathrm{c}$ & $1.5 \mathrm{c}$ & $2.0 \mathrm{~b}$ & $2.0 \mathrm{~b}$ & $2.0 \mathrm{~cd}$ \\
\hline Atlanta AG-303 & $1.5 \mathrm{~d}$ & $1.5 \mathrm{~d}$ & $1.5 \mathrm{~b}$ & $1.5 \mathrm{~b}$ & $1.5 \mathrm{c}$ & $1.5 \mathrm{c}$ & $1.5 \mathrm{~b}$ & $1.5 \mathrm{~b}$ & $1.5 \mathrm{~d}$ \\
\hline Average value & 3.5 & 3.5 & 3.6 & 3.7 & 3.7 & 3.8 & 3.8 & 3.8 & 3.9 \\
\hline
\end{tabular}

${ }^{1}$ Rating scale for leaf silvering, ranging from 1 (no symptom) to 5 (highest intensity of leaf-silvering) (escala de notas para o prateamento das folhas, variando de 1 a 5 , onde $1=$ ausência do sintoma; ... 5= grau máximo de prateamento na folha); ${ }^{2}$ The evaluations, from the $1^{\text {st }}$ to the $9^{\text {th }}$, were performed respectively, on $12^{\text {th }}, 15^{\text {th }}, 17^{\text {th }}, 19^{\text {th }}, 22^{\text {th }}, 24^{\text {th }}, 26^{\text {th }}, 29^{\text {th }}, 31^{\text {th }}$ December, 2003 and, the evaluations from the $10^{\text {th }}$ to the $18^{\text {th }}$, were performed respectively, on $2^{\text {nd }}, 5^{\text {th }}, 7^{\text {th }}, 9^{\text {th }}, 12^{\text {th }}, 14^{\text {th }}, 16^{\text {th }}, 19^{\text {th }}$ and $21^{\text {th }}$ January, 2004 (as avaliações, da primeira à nona, foram realizadas respectivamente nas datas de 12,15, 17, 19, 22, 24, 26, 29 e 31/12/2003 e, da décima à décima oitava, foram realizadas respectivamente nas datas de $2,5,7,9,12,15,16,19$ e 21/01/2004); *Averages followed by different letters in column are different by the Friedman test and by the nonparametric test of multiple comparisons (médias seguidas de letras distintas nas colunas diferem entre si pelo teste de Friedman e teste não paramétrico de comparações múltiplas $(\mathrm{p}<0,05))$. 
high infestation of $B$. tabaci biotype B throughout the cycle.

\section{REFERENCES}

ALVES AC. 2005. Resistência de genótipos de aboboreira a Bemisia tabaci biótipo $B e$ $a$ Trialeurodes vaporariorum (Hemiptera: Aleyrodidae). Campinas: Instituto Agronômico. 86p (Dissertação mestrado).

ALVES AC; LOURENÇÃO AL; MELO AMT. 2005. Resistência de genótipos de aboboreira a Bemisia tabaci (Genn.) biótipo B (Hemiptera: Aleyrodidae). Neotropical Entomology 34: 973-979.

BROWN JK; CZOSNEK H. 2002. Whitefly transmission of plant viruses. Advances in Botanical Research 36: 65-76.

BROWN JK; FROHLICH DR; ROSELL RC. 1995. The sweetpotato or silverleaf whiteflies: biotypes of Bemisia tabaci or a species complex? Annual Review of Entomology 40: 511-534.

BURGER Y; SCHWARTZ A; PARIS HS. 1988. Physiological and anatomical features of the silvering disorder of Cucurbita. Journal of Horticultural Sciences \& Biotechnology 63: 635-640.

CARDOZA YJ; McAUSLANE HJ; WEBB SE. 1999. Mechanisms of resistance to whitefly-induced squash silverleaf disorder in zucchini. Journal of Economic Entomology 92: 700-707.

CHEN J; McAUSLANE HJ; CARLE RB; WEBB SE. 2004. Impact of Bemisia argentifolii (Homoptera: Auchenorrhynca: Aleyrodidae) infestation and squash silverleaf disorder on zucchini yield and quality. Journal of Economic Entomology 97: 2083-2094.

COSTA HS; ULLMAN DE; JOHNSON MW; TABASHNIK BE. 1993. Squash silverleaf symptoms induced by immature, but not adult, Bemisia tabaci. Phytopathology 83 : 763-766.

DAVIDSON EW; SEGURA BJ; STEELE T; HENDRIX DL. 1994. Microorganisms influence the composition of honeydew produced by the silverleaf whitefly, Bemisia argentifolii. Journal of Insect Physiology 40: 1069-1076.

DE BARRO P; KHAN S. 2007. Adult Bemisia tabaci biotype B can induce silverleafing in squash. Bulletin of Entomological Research 97: 433-436.

DELATTE H; REYNAUD B; GRANIER M; THORNARY L; LETT JM; GOLDBACH R; PETERSCHMITT M. 2005. A new silverleaf-inducing biotype Ms of Bemisia tabaci (Hemiptera, Aleyrodidae) indigenous to the islands of the south-west Indian Ocean. Bulletin of Entomological Research 95: 29-35.

HENNEBERRY TJ; JECH LF; HENDRIX DL; STEELE T. 2000. Bemisia argentifolii (Homoptera: Aleyrodidae) honeydew and honeydew sugar relationships to sticky cotton. Southwestern Entomologist 25: 1-14.

HILJE L; MORALES FJ. 2008. Whitefly bioecology and management in Latin America. In: CAPINERA J (ed). Encyclopedia of entomology. Springer. p.4250-4260.

HOELMER KA; OSBORNE LS; YOKOMI RK. 1991. Foliage disorder in Florida associated with feeding by sweetpotato whitefly, Bemisia tabaci. Florida Entomologist 74: 162-166.

INBAR M; GERLING D. 2008. Plant-mediated interactions between whiteflies, herbivores, and natural enemies. Annual Review of Entomology 53: 431-448.

MAYNARD DN; CANTLIFFE DJ. 1989. Squash silverleaf and tomato irregular ripening: new vegetable disorders in Florida. Vegetable Crops Fact Sheet, VC-37, Florida Cooperative Extention Service, Institute of Food and Agricultural Sciences, Gainesville, Florida.
$4 p$.

McAUSLANE HJ; WEBB SE; ELMSTROM GW. 1996. Resistance in germplasm of Cucurbita pepo to silverleaf, a disorder associated with Bemisia argentifolii (Homoptera: Aleyrodidae). Florida Entomologist 79: 206-221.

McAUSLANE HJ; CHEN J; CARLE RB; SCHMALSTIG JG. 2004. Influence of Bemisia argentifolii (Homoptera: Aleyrodidae) and squash silverleaf disorder on zucchini seedling growth. Journal of Economic Entomology 97 : 1096-1105.

PARIS HS; NERSON H; BURGER Y. 1987. Leaf silvering of Cucurbita. Canadian Journal of Plant Science 67: 593-598.

PARIS HS; STOFFELLA PJ; POWELL CA. 1993. Differential susceptibility to leaf silvering in Cucurbita pepo. HortScience 28: 657-658.

RAIJ B van; CANTARELLA H; QUAGGIO JA; FURLANI AMC (eds). 1997. Recomendações de adubação e calagem para o estado de São Paulo. Campinas: Instituto Agronômico/ Fundação IAC. (Boletim Técnico, 100).

SCHUSTER DJ; KRING JB; PRICE JF. 1991. Association of the sweetpotato whitefly with a silverleaf disorder of squash. HortScience 26: 155-156.

SSERUWAGI P; LEGG JP; MARUTHI MN; COLVIN J; REY MEC; BROWN JK. 2005. Genetic diversity of Bemisia tabaci (Gennadius) (Hemiptera, Aleyrodidae) populations and presence of the $\mathrm{B}$ biotype and a non-B biotype that can induce silverleaf symptoms in squash, in Uganda. Annals of Applied Biology 147: 253-265.

WESSEL-BEAVER L. 1997. Screening for silverleaf resistance in Cucurbita accessions. Cucurbit Genetic Cooperation Report 20: 54-56.

YOKOMI RK; HOELMER KA; OSBORNE LS. 1990. Relationships between the sweetpotato whitefly and the squash silverleaf disorder. Phytopathology 80: 895-900 